\title{
URBAN NOISE AND BLOOD PRESSURE OF THE POPULATION - A SYSTEMATIC REVIEW OF STUDIES IN BELGRADE
}

\author{
GRADSKA BUKA I KRVNI PRITISAK STANOVNIŠTVA \\ - SISTEMATSKI PREGLED ISTRAŽIVANJA U BEOGRADU
}

\author{
Goran Belojević', Katarina Paunović', Branko Jakovljević', Vesna Stojanov ${ }^{2,3}$, Vesna Slepčević', Jelena llićŽivojinović
}

\section{Summary}

The Belgrade team for biological effects of noise, comprising experts in the fields of hygiene and cardiology, has carried out population studies in Belgrade on the sample of 2503 adults, 328 pre - school children and 1113 schoolchildren to investigate the effects of urban noise on blood pressure. In the first phase of investigation acoustic measurements were performed on 115 streets of the central municipality "Stari grad" as a typical urban environment. Blood pressure measurements were performed using mercury sphygmomanometer in those subjects who did not have a diagnosed hypertension and were not under antihypertensive therapy. Among adults living in the streets with equivalent noise level (Leq) exceeding $45 \mathrm{~dB}(\mathrm{~A})$ there was a significantly higher number of people with hypertension compared to areas with Leq $\leq 45 \mathrm{~dB}$ (A) (23.6\% vs.17.5\%). After statistical adjustments according to family history of hypertension, age, body mass index (BMI), smoking habits, physical activity and alcohol consumption among males, we found $58 \%$ increased odds for obtaining hypertension if they lived in noisy environments for more than 10 years $(O R=1.58 ; 95 \mathrm{Cl}=1.03-2.42 ; \mathrm{p}=0.038)$. In females noise exposure and hypertension were not significantly related. In pre - school children aged $3-7$ and living in areas with night $L$ eq $>45 \mathrm{~dB}(\mathrm{~A})$ and attending kindergartens in the streets with daytime Leq $>60 \mathrm{~dB}$ (A) the prevalence of hypertensive values of blood pressure was higher compared to children from quiet streets $(5,7 \%$ vs. $1,5 \% ; p=0,054)$. Systolic blood pressure was significantly higher (5 mmHg on average) in children from noisy streets and kindergartens compared to children from quiet environments $(p<0,01)$. Multiple regression after adjustments according to age, sex, BMI percentile-for-age, family history of hypertension, and socioeconomic status revealed a significant positive correlation between the exposure to urban noise and systolic blood pressure $(p=0,009)$. In schoolchildren aged $7-11$ and attending schools in streets with public transport we found a higher systolic blood pressure ( $1.3 \mathrm{mmHg}$ on average) compared to children from schools without public transport, after adjustments according to age, sex, BMI, family history of hypertension, living conditions and health related behavioral habits $(\mathrm{p}<0.05)$.

Key words: community noise; blood pressure; hypertension, children, adults.

\section{Sažetak}

Beogradski tim za biološke efekte buke koji čine stručnjaci iz oblasti higijene i kardiologije sproveo je populacione studije u Beogradu na uzorcima od 2503 odrasle osobe, 328 predškolske dece i 1113 školske dece o uticaju komunalne buke na krvni pritisak. Opština Stari Grad kao tipično gradska sredina poslužila je kao područje na kojem su u prvoj fazi istraživanja sprovedena akustička merenja u 115 ulica. Merenja krvnog pritiska obavljana su živinim sfigmomanometrom kod onih ispitanika kod kojih nije dijagnostikovana hipertenzija i ne uzimaju terapiju. Kod odraslog stanovništva koje živi u ulicama sa ekvivalentnim nivoom noćne buke iznad $45 \mathrm{~dB}$ (A) bilo je značajno više ispitanika sa hipertenzijom u odnosu na sredine sa noćnom bukom $\leq 45 \mathrm{~dB}$ (A) (23.6\% vs. 17.5\%). Posle statističkog prilagođavanja u odnosu na porodičnu istoriju hipertenzije, dob, BMI, pušačke navike, fizičku aktivnost i konzumiranje alkohola, za muškarce je utvrđena za $58 \%$ veća šansa da dobiju hipertenziju ukoliko žive u bučnoj sredini duže od 10 godina $(O R=1.58 ; 95(\mathrm{l}=1.03-2.42 ; \mathrm{p}=0.038)$, dok kod žena uticaj buke na pojavu hipertenzije nije značajan. Kod predškolske dece uzrasta 3-7 godina koja žive u sredini sa noćnom bukom Leq $>45 \mathrm{~dB}$ (A) i koja idu u obdaništa u ulicama sa dnevnim nivoom buke Leq $>60 \mathrm{~dB}$ (A) prevalencija hipertenzivnih vrednosti krvnog pritiska bila je viša nego kod dece iz tihih ulica $(5,7$ vs. 1,$5 ; p=0,054)$. Sistolni pritisak bio značajno viši ( 5 mmHg u proseku) kod dece iz bučnih ulica i obdaništa u poređenju sa decom iz tihe obe sredine $(p<0,01)$. Multipna regresiona analiza posle prilagođavanja u odnosu na dob, pol, percentil BMI u odnosu na dob, porodičnu istroriju hipertenzije i socioekonomski status pokazala je značajnu pozitivnu korelaciju između izlaganja dece komunalnoj buci i sistolnog pritiska $(p=0,009)$. Kod školske dece uzrasta 7-11 godina nađeno je da ukoliko su njihove škole locirane u ulici sa javnim saobraćajem sistolni pritisak je viši za $1.3 \mathrm{mmHg}$ u odnosu na decu iz škola bez javnog saobraćaja, posle prilagođavanja u odnosu na dob, pol, BMI, porodičnu istoriju hipertenzije, uslove stanovanja i zdravstveno značajne navike $(p<0.05)$.

Ključne reči: komunalna buka, krvni pritisak, hipertenzija, deca, odrasli 


\section{INTRODUCTION}

Urban noise is an emerging environmental problem both in developed and developing countries. More than 50\% of the European population is annoyed by unacceptable daytime equivalent noise levels (Leq) exceeding $55 \mathrm{~dB}$ while about one third of the population complains of sleep disorders due to exposure to night time Leq exceeding $45 \mathrm{~dB}$. (1) Road-traffic noise exposure is also an ever increasing environmental problem in Serbian towns, especially in Belgrade, where daytime and nighttime noise limits are regularly exceeded by $10-20 \mathrm{~dB}$. (2)

Hypertension is one of the major risk factors for early death in urban populations due to its association with the incidence of stroke, myocardial infarction, heart failure and end - stage renal disease. (3) The link between urban noise and hypertension has been intensively studied in the past three decades. A recent meta - analysis based on 24 cross - sectional studies on the association between road traffic noise and the prevalence of hypertension showed an odds ratio (OR) of 1.07 (95\% confidence interval $(\mathrm{CI})=1.02-1.12, P<0.05)$ per $10 \mathrm{~dB}$ increase of the 16 -h day - time average road traffic noise level $\left(L_{\text {Aeq16h }}\right)$ in the range of $<50$ to $>75 \mathrm{~dB}$. (4) Pathophysiological concept explaining the relationship between noise and hypertension is based on a general stress - reaction model. (5-6) Noise activates the hypothalamic - pituitary - adrenal axis and sympathetic nervous system and stimulates reticular formation with a consequent increase in the circulatory catecholamines and cortisol, which are of substantial importance for blood pressure (BP) regulation. (7)

The research of the Belgrade Team of Biological Effects of Noise (BETBEN) from the Faculty of Medicine University of Belgrade over the past decade has focused on two main scientific problems that were not sufficiently studied in previous investigations: nighttime noise in residential areas and noise around schools and kindergartens and $\mathrm{BP}$ of adults and children.

The World Health Organization has recognized nighttime noise as an important stressor related to diseases with the mediating effect of sleep deprivation. (8) However, commonly used daytime noise measurements in residential areas in the investigations on the relationship between noise and hypertension may be the source of exposure bias, because people, and especially children, usually spend most of their daytime hours out of home. (9) It may be assumed that nighttime noise measurements would alleviate the possible bias problem. Beside studies on adults, of special scientific relevance are investigations on children's BP and noise exposure due to small body of evidence and rather conflicting results from previous studies. There are reports both on the positive correlation between noise exposure and children's BP (10-11) and on the negative association. (12)
This is the review of the studies performed by BETBEN in Belgrade on the effects of road traffic noise on the BP among adults and children. (13-16)

The tested null hypotheses in our studies were: 1 . Nighttime noise in residential areas is not related to changes in BP among urban adult population and children; 2. There is no association between daytime road traffic noise around schools and kindergartens and $\mathrm{BP}$ among children.

The aims of our studies were: 1 . To compare the prevalence of hypertension between the adult population living in residential areas with nighttime Leq over and equal/below the adopted outdoor nighttime noise limit of $45 \mathrm{~dB} ; 2$. To investigate the effects of road traffic noise around kindergartens and nighttime noise around residences on BP levels of pre-school children; 3. To explore the effects of road traffic noise around schools and nighttime noise around residences on BP levels of schoolchildren. 4. To investigate the relationship between the presence of public transport as noise indicator and children's BP.

\section{Methods}

Study samples

\section{Adults}

A cross - sectional study was performed on a sample of the adult population in a downtown Belgrade municipality. The estimated adult population of this municipality, according to the census data, was about 60.000 . To obtain a $10 \%$ randomized sample of 6000 people, we used a step method in interviewing all adult residents of every tenth flat in all the streets. The appropriate numbers of questionnaires were delivered to post boxes inside the buildings according to the list of dwellers. The response rate was $52.8 \%$, or 3169 completed questionnaires. The inclusion criteria for selecting the final subsample of residents were the period of residence longer than 10 years and a bedroom overlooking the street. The exclusion criteria included a high level of noise annoyance at work and the presence of diseases that might influence the occurrence of hypertension. Using these criteria, the sample was further reduced to 2,803 residents, 1,095 men and 1,708 women. The subjects who reported taking antihypertensive drugs were classified into a group with hypertension ( $n=318,139$ men and 179 women). Subjects who denied having medically confirmed hypertension or taking antihypertensive drugs $(n=2,485)$ were contacted by phone and invited for BP measurement. The response rate was $87.9 \%(n=2,185,856$ men and 1,329 women). The final sample for investigation thus included a total of 2,503 subjects (995 men with an average age of 42,18 years [range 18-96 years] and 1,508 women with an average age of 40,17 years [range 18-91 years]). 
Pre-school children

A cross - sectional study was performed on children aged 3 - 7 residing in a downtown Belgrade municipality, who attended 10 public kindergartens. Parents took the children to the kindergartens between 6 a.m. and 8 a.m. and brought them back home between 3 p.m. and 6 p.m. Parents were informed about the study and interviewed to obtain their approval for the examination of their children. The inclusion criteria for the sample were three or more years living on the present address and orientation of a child's bedroom towards the streets. The exclusion criterion for the sample was the presence of chronic diseases affecting arterial BP (diabetes mellitus and/or renal diseases). Out of 710 interviewed parents, 446 (62.8\%) returned the questionnaires with the approval for examination. After applying the inclusion and exclusion criteria [living on the present address for less than 3 years $(n=21)$; bedroom not oriented towards the street $(\mathrm{n}=95)$; diabetes mellitus $(\mathrm{n}=1)$; renal diseases $(\mathrm{n}=1)]$ the final sample consisted of 328 children (174 boys and 154 girls). The study sample was divided into four subsamples of children according to noise levels in the environment of residences and kindergartens. The environment of residence was regarded noisy if Leq exceeded $45 \mathrm{~dB}(\mathrm{~A})$ during night (10 p.m. to 6 a.m.), and quiet if the Leq was $\leq 45 \mathrm{~dB}(\mathrm{~A})$. The average Leq of noisy and quiet residences were $55.5 \pm 6.7 \mathrm{~dB}(\mathrm{~A})$ and $41.8 \pm 3.0$ $\mathrm{dB}(\mathrm{A})$, respectively. The environment of kindergarten was regarded noisy if daily Leq exceeded $60 \mathrm{~dB}(\mathrm{~A})$, and quiet if Leq was $\leq 60 \mathrm{~dB}(\mathrm{~A})$. The average Leq of the noisy and quiet kindergartens were $66.9 \pm 5.3 \mathrm{~dB}(\mathrm{~A})$ and $55.7 \pm 2.8 \mathrm{~dB}(\mathrm{~A})$, respectively. The four subsamples were created by applying the following acoustical characteristics of children's residences and kindergartens: 1. Quiet residence and quiet kindergarten $(n=60 ; 29$ boys and 31 girls); 2. Quiet residence and noisy kindergarten ( $\mathrm{n}=75 ; 39$ boys and 36 girls); 3 . Noisy residence and quiet kindergarten ( $\mathrm{n}=62 ; 37$ boys and 25 girls), and 4 . Noisy residence and noisy kindergarten ( $\mathrm{n}=131 ; 69$ boys and 62 girls).

\section{Schoolchildren}

A cross - sectional study was conducted in the municipality Stari grad, located in the center of Belgrade. This municipality is an administrative and residential area with road traffic as the principal source of noise. In total, eight public primary schools are located in this municipality. Investigators contacted children aged 7 11 (1st to 4th grade) and their parents through school boards. In the pilot study (15) the sample included 391 children (186 boys, 205 girls). Of 2000 interviewed parents in the final investigation (16), 1150 (57.5\%) returned the questionnaires with the signed approval for examination of their children. Children gave their written consent for participating in this study. Ethics Committee of the Faculty of Medicine in Belgrade approved the study. The only exclusion criterion was the presence of chronic diseases affecting arterial BP (diabetes mel- litus, heart or kidney diseases). Apart from pupils with diabetes $(n=3)$ and those absent from school on the day of examination $(n=34)$, the final sample consisted of 1113 children (533 boys and 580 girls).

\section{Noise Measurements}

Noise levels were measured in all 115 streets of the central Belgrade municipality "Stari grad", as well as in front of 10 public kindergartens and eight elementary schools.

Hand - Held noise level analyzer type 2250 "Brüel and Kjær" was used, according to recommendations of International Standard Organization for the measurement of community noise (17). Noise levels were measured in the middle of the street. Noise was measured in two intervals during the day (between 10 a.m. and noon, and between 2 p.m. and 4 p.m.), in one evening interval (between 6 p.m. and 8 p.m.), and in two night intervals (between 10 p.m. and 12 p.m., and between midnight and 2 a.m.) In front of each kindergarten noise measurements were performed in two daily periods ( 9 a.m. -10.30 a.m. and 1.30 p.m.-3 p.m.). Noise levels around schools were measured on week days during lessons in two morning intervals (between 9 a.m. and 11 a.m., and between noon and 2 p.m.) and one afternoon interval (between 3 p.m. and 5 p.m.). The instrument was positioned on the pavement near the road; the time interval of each measurement was $15 \mathrm{~min}$; the speed of sampling was $10 / \mathrm{sec}$, with 9000 samples collected per measurement. Noise measurements were performed on several week days for each school; the measurements took place a few weeks after the examination of children in order to avoid researcher bias related to awareness of noise levels and traffic density.

A composite daytime equivalent noise level (Leq) was calculated for each kindergarten and school; a composite daytime and night time Leq levels were calculated for each street from the obtained emission noise values.

\section{Blood Pressure Measurement}

\section{Adults}

Participants were asked to avoid drinking coffee or smoking for half an hour before physical examination. A cardiologist took the BP measurements with a Fazzini mercury sphygmomanometer (cuff sizes 50-60 $\mathrm{cm}$; width 14-17 cm; Fazzini, Italy). This instrument complies with the decision of Annex VI of the European Council Directive 93/42/EEC concerning medical devices. The measurements were performed on a week day in an outpatient department, between noon and 2 p.m., after a short rest of about $5 \mathrm{~min}$. The subject was in a sitting position, and the mean value was determined from two measurements performed on each arm. If the difference between measurements exceeded $5 \mathrm{mmHg}$, a third measurement was performed on the same arm. 
Hypertension was diagnosed according to the criteria established by the Seventh Report of the Joint National Committee on Detection, Evaluation, and Treatment of High Blood Pressure (systolic pressure $\geq 140 \mathrm{mmHg}$ and/or diastolic pressure $\geq 90 \mathrm{mmHg}$ ) (18). Ambulatory BP monitoring was applied in 175 participants (64 men and 111 women) with borderline BP levels and fluctuation from normal to hypertensive values. BP was measured every $30 \mathrm{~min}$ over a 24 -h period including both waking and sleeping hours on weekdays. The criteria for hypertension based on the ambulatory BP measurements were a mean systolic pressure $>135 \mathrm{mmHg}$ and/or a mean diastolic pressure $>85 \mathrm{mmHg}$ (18). The proportion of subjects in whom hypertension was diagnosed through the BP measuring procedure was $7.5 \%$ $(n=163)$, out of which there were 79 men $(9.2 \%)$ and 84 women (6.3\%). Within this group, 98 cases of hypertension ( 52 men and 46 women) were diagnosed by BP measurement with a sphygmomanometer, and 65 cases of hypertension (27 men and 38 women) were diagnosed by additional ambulatory BP monitoring. In the whole investigated sample the total proportion of subjects with hypertension was $19.2 \%(n=481)$ out of which there were 218 men (21.9\%) and 263 women (17.4\%).

\section{Children}

Children's BP was measured using mercury sphygmomanometer "Fazzini", Italy in a kindergarten or a school. Cuff sizes of $7.5 \times 19.5 \mathrm{~cm}$ or $11 \times 27 \mathrm{~cm}$ were used according to arm measurement criteria (19). This instrument complies with the decision according to Annex VI of the Council Directive 93/42/EEC concerning medical devices. The measurements were performed after a 15 - minute rest, in a sitting position, with a child's right arm at heart level. Two measurements were performed on the right arm with five minute interval. If the difference between measured BP levels exceeded $5 \mathrm{~mm}$ $\mathrm{Hg}$, the third measurement was performed and mean values of systolic and diastolic pressures were calculated. Heart rate was measured by radial artery palpitation for $1 \mathrm{~min}$. The measurements were performed by one of two researchers - medical doctors trained according to the study protocol. Children were not allowed to talk during the measurement session. Hypertension was diagnosed if systolic and/or diastolic pressure were equal or exceeding 95th percentile of values, according to body height, sex, and age (20).

\section{QUESTIONNAIRES}

\section{Adults}

The questionnaire was anonymous and it consisted of two segments. The first part comprised general socio - demographic data: age, sex, education, employment, period of residence, daily time spent in the apartment, apartment size, number of dwellers, and orientation of the bedroom(s) (toward the street or not).
The second segment consisted of questions on antihypertensive therapy and possible confounding factors, such as family history of hypertension, body weight and height, smoking habits, physical activity, and alcohol consumption, graded on a six - point scale (0: never; 1: several times a year; $2: 1-3$ times a month; $3: 1-3$ times a week; 4: $4-6$ times a week; and 5: every day). There were also questions concerning medically confirmed diseases related to hypertension: diabetes mellitus, renal diseases, aortal coarctation, Cushing's Syndrome, hyperthyreosis, pheochromocytoma, primary aldosteronism, acromegaly and hyperparathyroidism.

\section{Children}

The questionnaire consisted of two segments. The first part comprised general socio-demographic data: child's age, sex, birth by order, parental education (coded as: 1-elementary school; 2-secondary school; 3-college; 4-faculty), parental employment, marital status, monthly income (coded as: 1-insufficient; 2-sufficient; 3 -more than sufficient), apartment size, number of dwellers, floor The second part of the questionnaire consisted of questions on family history of hypertension, child's birth weight and diseases related to arterial hypertension (diabetes mellitus, renal diseases).

\section{Statistical ANALYsis}

Data are presented as the means \pm SD for numeric variables, or as percentages (relative numbers) for categorical variables. Differences between groups in parametric data were compared using Student's $t$-test and one - way ANOVA [followed by Least Significant Difference Test (LSD) post hoc analysis]. Mann Whitney U-test and Chi-square test were used for nonparametric data. Pearson correlation analysis was performed to test the association between variables from the questionnaire and children's BP and heart rate. Based on the results of univariate analyses, variables significantly related to $\mathrm{BP}$ and heart rate were included in a multiple linear regression model. Univariate logistic regression was performed to calculate OR for arterial hypertension in relation to relevant independent variables. Multiple logistic regression was used to calculate adjusted OR for arterial hypertension in relation to noise exposure. A probability level of less than 0.05 was accepted as significant. We used SPSS 15.0 for Windows software (SPSS Inc. 1989-2006)

\section{Results}

Main findings of the performed studies in Belgrade are presented in Table 1.

The prevalence of hypertension among male adults living in residential areas with a higher nighttime noise level 
Table 1. Main findings of the studies in Belgrade on the relationship between noise exposure and blood pressure of the population

\begin{tabular}{|c|c|c|c|c|c|c|}
\hline Reference & Design & Sample size & $\begin{array}{l}\text { Exposure assess- } \\
\text { ment method }\end{array}$ & $\begin{array}{l}\text { Blood } \\
\text { pressure } \\
\text { measurement }\end{array}$ & Main finding & Effect Size \\
\hline $\begin{array}{l}\text { Belojevic et } \\
\text { al. (13) }\end{array}$ & $\begin{array}{l}\text { Cross- } \\
\text {-sectional }\end{array}$ & $\begin{array}{l}2503 \text { adults }(995 \\
\text { male } \& 1508 \\
\text { female) } \\
\text { Belgrade }\end{array}$ & $\begin{array}{l}\text { L night } 8 \mathrm{~h}>45 \\
\text { dB (A) vs. } \leq 45 \\
\text { dB (A) }\end{array}$ & $\begin{array}{l}\text { Diagnosed hy- } \\
\text { pertension \& } \\
\text { Sphygmoma- } \\
\text { nometer mea- } \\
\text { surement }\end{array}$ & $\begin{array}{l}\text { Higher prevalence of and } \\
\text { odds for hypertension } \\
\text { among males exposed to } \mathrm{L} \\
\text { night } 8 \mathrm{~h}>45 \mathrm{~dB} \text { (A) vs. } \leq \\
45 \mathrm{~dB} \text { (A) }\end{array}$ & $\begin{array}{l}\text { OR }(95 \% \text { CI }) 1.58 \\
(1.03-2.42)\end{array}$ \\
\hline $\begin{array}{l}\text { Belojevic et } \\
\text { al. (14) }\end{array}$ & $\begin{array}{l}\text { Cross- } \\
\text {-sectional }\end{array}$ & $\begin{array}{l}328 \text { preschool } \\
\text { children (age } \\
3-7) 174 \text { boys, } \\
154 \text { girls, Bel- } \\
\text { grade }\end{array}$ & $\begin{array}{l}\text { Lnight, } \leq 45 \mathrm{~dB} \\
\text { (A) vs. }>45 \mathrm{~dB} \\
\text { (A); kindergar- } \\
\text { ten: Lday, } \leq 60 \\
\text { dB (A) vs. }>60 \\
\text { dB (A) }\end{array}$ & $\begin{array}{l}\text { Sphygmoma- } \\
\text { no-meter mea- } \\
\text { surement }\end{array}$ & $\begin{array}{l}\text { More children with hyper- } \\
\text { tensive values of BP and } \\
\text { higher systolic BP from } \\
\text { noisy residences and kin- } \\
\text { dergartens vs. quiet resi- } \\
\text { dences and kindergartens }\end{array}$ & $\begin{array}{l}5.70 \% \text { vs. } 1.48 \% \\
\mathrm{p}=0.054: 5 \mathrm{~mm} \\
\text { Hg mean differ- } \\
\text { ence } \\
(\mathrm{P}<0.01)\end{array}$ \\
\hline $\begin{array}{l}\text { Belojevic et } \\
\text { al. (15) }\end{array}$ & $\begin{array}{l}\text { Cross- } \\
\text {-sectional }\end{array}$ & $\begin{array}{l}391 \text { schoolchil- } \\
\text { dren (age } 7-11) \\
186 \text { boys , 205 } \\
\text { girls, Belgrade }\end{array}$ & $\begin{array}{l}\text { Lnight, } \leq 45 \\
\text { dB (A) vs. > } 45 \\
\text { dB (A); School: } \\
\text { Lday, } \leq 60 \mathrm{~dB}(\mathrm{~A}) \\
\text { vs. }>60 \mathrm{~dB}(\mathrm{~A})\end{array}$ & $\begin{array}{l}\text { Sphygmoma- } \\
\text { no-meter mea- } \\
\text { surement }\end{array}$ & $\begin{array}{l}\text { Higher systolic BP among } \\
\text { children from noisy resi- } \\
\text { dences and schools vs. quiet } \\
\text { residences and schools }\end{array}$ & $\begin{array}{l}4 \mathrm{~mm} \mathrm{Hg} \text { mean } \\
\text { difference } \\
(\mathrm{P}<0.01)\end{array}$ \\
\hline $\begin{array}{l}\text { Paunovic et } \\
\text { al. (16) }\end{array}$ & $\begin{array}{l}\text { Cross- } \\
\text {-sectional }\end{array}$ & $\begin{array}{l}1113 \text { schoolchil- } \\
\text { dren ( } 533 \text { boys; } \\
580 \text { girls) }\end{array}$ & & $\begin{array}{l}\text { Sphygmoma- } \\
\text { no-meter mea- } \\
\text { surement }\end{array}$ & $\begin{array}{l}\text { Higher systolic BP among } \\
\text { children from residences } \\
\text { and schools from the streets } \\
\text { with public transport vs. no } \\
\text { public transport }\end{array}$ & $\begin{array}{l}2 \mathrm{~mm} \mathrm{Hg} \text { mean } \\
\text { difference } \\
(\mathrm{P}<0.05)\end{array}$ \\
\hline
\end{tabular}

was higher compared to the population from less noisy areas $(23.6 \%$ vs. $17.5 \%)$. Odds ratio adjusted for age, body mass index, physical activity, subjective noise sensitivity, noise annoyance, family history of hypertension and alcohol consumption pointed to $58 \%$ higher probability of obtaining hypertension if exposed to noise. There was no significant effect of noise on BP of females.

Systolic pressure was significantly higher $(5 \mathrm{~mm} \mathrm{Hg}$ on average) among pre-school children from noisy residences and kindergartens compared to children from both quiet environments $(p=0.001)$. Diastolic pressure and mean arterial pressure were similar between the groups. The prevalence of children with hypertensive values of BP was 3.96\% (13 children, including 8 boys and 5 girls), with higher prevalence in children from noisy residences $(5.70 \%)$, compared to children from quiet residences (1.48\%). The difference was borderline significant $(\chi 2=3.71 ; \mathrm{p}=0.054)$. To determine the relationship between noise exposure and studied cardiovascular parameters allowing for age, parental education, family history of hypertension and family income, multiple linear regression analysis was performed. The correlation was positive and significant $(\mathrm{B}=1.056(95 \% \mathrm{CI}=0.269-1.843)(\mathrm{P}=0.009))$.

In the pilot study on school children (15) the systolic BP among children from noisy residences and schools was higher compared to children from quiet residences and schools. The multiple linear regression adjusted for age, parental education, family history of hypertension and family income showed that systolic pressure was positively and significantly related to noise exposure $(\mathrm{B}=$ $3.413(95 \% \mathrm{CI}=1.903-4.923)(\mathrm{P}<0.001))$.
The final study on schoolchildren showed that children attending schools with public transport running nearby had by $1.3 \mathrm{mmHg}$ higher systolic BP compared to children from schools without public transport. (16) This effect was independent from children's age, gender, BMI, family history of hypertension, physical activity and eating habits.

\section{Discussion}

Our investigations show that nighttime road - traffic noise is significantly related to hypertension in the adult male urban population. We also show that systolic pressure is higher among children exposed to noise at home and at kindergartens or schools, compared to children from two quiet environments. There is a possible positive association between the presence of public transport near schools and systolic BP in schoolchildren.

So far, few studies have focused on the influence of nighttime noise. One of these is a study conducted in the city of Erfurt in Germany. It was designed as a longitudinal 5 - year prospective study investigating health benefits of lowering traffic noise levels by $10 \mathrm{~dB}(\mathrm{~A})$ in the residential area. (21) The results showed that the recovery of the patients with arterial hypertension was more frequent than in the control group where no such measures were undertaken. Only one German survey distinguished the effects of nighttime $v s$. daytime noise exposure, showing slightly higher relative risk for hypertension in association with night noise (22). That study revealed significant risk for the occurrence of hypertension among men exposed to nighttime noise 
levels exceeding $55 \mathrm{~dB}(\mathrm{~A})$, independent from other possible confounders, including age, body mass index, physical activity or family history of hypertension.

The presented results on noise exposure and children's BP are partially in accordance with the results from Bratislava study on preschool children (11) and with the Inn Valley study (10). In the Bratislava study significantly higher systolic and diastolic BP readings were reported in children aged $3-7$, from homes and/or kindergartens exposed to traffic noise of Leq $24 \mathrm{hN} 60 \mathrm{~dB}$ compared to those from less exposed areas (Leq24h $\leq 60 \mathrm{~dB}$ ). The findings of the London study (12) were mainly opposite to our results, showing significant negative association between daytime road - traffic noise at schools and children's systolic pressure. However, the effect of road - traffic noise at home was not investigated. Daytime and night time aircraft noises at home were significantly and positively associated with BP.

The clinical significance of the observed $2-5 \mathrm{~mm} \mathrm{Hg}$ difference in the mean systolic pressure level between children exposed to higher and lower noise levels is difficult to determine. It is also challenging to predict whether and to what extent slight increases in children's $\mathrm{BP}$ can cause possible health risks in later life, although there is evidence that elevated BP values in childhood might be related to hypertension in young adults (23).

\section{Conclusion}

The investigations of the BETBEN over the past decade show that road traffic noise might be regarded as a significant risk factor for hypertension in adult urban population and an important stressor that might elevate systolic BP in children.

\section{NAPOMENA}

Rad je usmeno izložen na mini simpozijumu Higijensko-ekološki činioci i zdravlje na 43. simpozijumu Stremljenja i novine u medicini, Medicinski fakultet u Beogra$d u, 12.12 .2014$. godine.

\section{References}

1. Berglund B, Lindvall T, Schwella DH. (eds.) Guidelines for community noise. World Health Organization, Geneva, 1999, pp. 1-2

2. Institute of Public Health of Belgrade. Ecological atlas of Belgrade. Final document of the second stage of the project 'ecological assessment of the general urban plan of Belgrade'. Vol. B. Cartographic reports on the sectors analyses (CDROM). Belgrade (Serbia): GZZZ; 2002.

3. Mancia G, Fagard R, Narkiewicz K, et al. 2013 ESH/ESC Guidelines for the management of arterial hypertension. J Hypertens 2013; 31 (7): 1281-357.

4. van Kempen E, Babisch W. The quantitative relationship between road traffic noise and hypertension: a meta-analysis. J Hypertens. 2012; 30 (6):1075-1086

5. Babisch W. Cardiovascular effects of noise. Noise Health. 2011;13 (52):201-204.

6. Münzel T, Gori T, Babisch W,_Basner M. Cardiovascular effects of environmental noise exposure. Eur Heart J. 2014 35(13): 829-836.

7. Babisch W. Stress hormones in the research on cardiovascular effects of noise. Noise Health. 2003; 5(18):1-11.

8. World Health Organization. Night noise guidelines for Europe. WHO Regional Office for Europe, Copenhagen, 2009.

9. Xue J, McCurdy T, Spengler J, Ozkaynak H. Understanding variability in time spent in selected locations for 7-12 year old children. J Exp Anal Environ Epidemiol 2004; 14 (3):222-33.

10. Evans GW, Lercher P, Meis M, Ising H, Kofler W. Community noise exposure and stress in children. J Acoust Soc Am 2001; 109 (3):1023-7.

11. Regecova V, Kellerova E. Effects of urban noise pollution on blood pressure and heart rate in preschool children. J Hypertension 1995; 13 (4):405-12.

12. Van Kempen E, Van Kamp I, Fischer P, et al. Noise exposure and children's blood pressure and heart rate: the RANCH project. Occup Environ Med 2006; 63(9):632-9.

13. Belojević G, Jakovljević B, Stojanov V, Slepčević V, Paunović K. Nighttime road-traffic noise and arterial hypertension in an urban population. Hypertens Res 2008; 37: 775-81.

14. Belojevic G, Jakovljevic B, Stojanov V, Paunovic K, Ilic J. Urban road-traffic noise and blood pressure and heart rate in preschool children. Environ Int 2008; 34:226-231.

15. Belojevic G, Jakovljevic B, Paunovic K, Stojanov V, Ilic J. Urban road-traffic noise and blood pressure in school children. In: Griefahn B (Ed.) Proceedings of the 9th Congress of the International Commission on Biological Effects of Noise „Noise as a Public Health Problem“, Mashantucket, Foxwoods, CT, USA, 21-25 July 2008, pp.287-292.

16. Paunovic K, Belojevic G, Jakovljevic B. Blood pressure of urban school children in relation to road traffic noise, traffic density and presence of public transport. Noise Health 2013; 15 (65): 253-260.

17. ISO (International Organization for Standardization). Acousticsdescription and measurement of environmental noise-Part 1, Basic quantities and procedures. International Standard. ISO 1996-1. Geneva: International Organization for Standardization; 1982.

18. National Institute of Health, National Heart, Lung, and Blood Institute: The Seventh Report of the Joint National Committee on Detection, Evaluation, and Treatment of High Blood Pressure. NIH Publication No. 03-5233, 2003.

19. Kirkendall WM, Feinleib M, Freis ED, Mark AL. Recommendations for human blood pressure determination by sphygmomanometers. Subcommittee of the AHA Postgraduate Education Committee. Hypertension 1981; 3 (4):510A-9A.

20. National High Blood Pressure Education Program. Working Group on High Blood Pressure in Children and Adolescents. The fourth report on the diagnosis, evaluation and treatment on high blood pressure in children and adolescents. Pediatrics 2004; 114 (2):555-76.

21. WöIke C, Mahr B, Kahl G, Morstedt R, Schulze B: Traffic noise and cardiovascular risk. Forum Städte-Hygiene 1990; 41: 306-308 (in German).

22. Maschke C, Wolf U, Leitmann T: Epidemiological examinations of the influence of noise stress on the immune system and the emergence of arteriosclerosis. Report 29862 515, WaBoLu-Hefte, 01/03. Umweltbundesamt, Berlin, 2003 (in German, executive summary in English).

23. Bao W, Threefoot SA, Srinivasan SR, Berenson GS (1995). Essential hypertension predicted by tracking of elevated blood pressure from childhood to adulthood: the Bogalusa Heart Study. Am J Hypertens 8: 657-665. 